\title{
Employee Engagement and Retention in Automotive Industry in Malaysian Context. Job Stress as a Moderator
}

\author{
Vimala Kadiresan, Wong Sook Khuan, Thangaraja Arumugam, Farrell Rasu, Anastashia \\ Shawna Theseira
}

\begin{abstract}
Employee engagement has been extensively researched lately as it delivers a positive business outcome. Due to the complex competition prevailing in the automotive industry, maintaining a high-level engagement among the employees is important for long term business performance. The level of employee engagement can be improved by identifying its drivers. For this purpose of study, The Malaysian automotive industry was chosen as it plays a significant role in the manufacturing sector which drives towards industrialization nation, hence contributing to the Malaysian economy. The drivers of employee engagement are identified as (rewards and recognition, leadership, empowerment, compensation and career development) and their relationship between employee engagements are examined. Furthermore, Job stress was used as a moderator to examine the relationship of Employee Engagement and Retention. 288 responded from this industry in Malaysia based on random sampling and Structural equation modelling (SEM) was utilised as statistical tools to perform the analysis. It is hoped that this study will benefit many organizations, especially the employers and human resource managers in Malaysia by developing a better understanding on the importance of employee engagement within the organization, in a way, which could improve the performance of the business competitiveness and retain the employees
\end{abstract}

Keywords: Engagement, Retention, Job Stress, Automotive Industry, Career Development, Leadership, Empowerment, Compensation

\section{INTRODUCTION}

Malaysia is a developing country that has ventured into the automotive industry. More high value jobs are available across Malaysia due to the advancement of the automotive industry [1]. Indeed, the automotive industry has greatly contributed to the economy growth in Malaysia. Malaysia also ranked ninth in the world, with the greatest number of automobile production with 511,165 , as of July 2018 [2]. However, as claimed by [3] automotive industry in Malaysia is lack of marketing capability and weak in technological due to failure in industrial upgrading and global competitiveness. For instance, weak product development and marketing

Revised Manuscript Received on September 22, 2019.

Vimala Kadiresan*, HELP University, Selangor,Malaysia vimala.k@help.edu.my

Wong Sook Khuan, KDU University College, Malaysia

Thangaraja Arumugam, Vellore Institute of Technology, Chennai, Tamilnadu, India.

Farrell Rasu, National Institute of Public Administration (INTAN), Bukit Kiara, Kuala Lumpur , Malaysia

Anastashia Shawna Theseira Segi University, Kota Damansara , Selangor, Malaysia capacity of Proton failed to meet customers' satisfaction [4]. Besides, the automotive suppliers are also facing problems related to quality of components and parts [5]. Moreover, per employee's productivity or average sales value in automotive industry in 2015 has decreased by $3.5 \%$ as compared to year 2014 even though sales value has increased by $0.1 \%$ [6]. These could be due to issues in employee engagement in the automotive industry which lead employees to be demotivated. According to the Gallup's findings on "The State of the Global Workplace: Employee Engagement Insights for Business Leaders Worldwide report", engagement level of employees in Malaysia is $11 \%$, whereas $81 \%$ disengaged and $8 \%$ actively disengaged [7].

Job stress is also a concern in employee engagement and retention. When job stress occurs in the workplace, it leads to a low employee engagement which contributes to a low-quality product whereby reducing the customer's satisfaction in the automotive industry [8]. Thus, this becomes a stumbling block to the employees in fully expressing their job performance by not being creative or contributing ideas on product development [9],[10]. The disengaged employees may cause negative corporate reputation as they are least concerned on organization benefits and success [11]. Similarly, when there is a reduction in employee engagement due to excessive stress, it will also affect the employees' performance [12]. Some employees may decide to move to another organization due to their heavy workload at work which creates stress thus leading to low engagement [13].

Retention is a key element for an organization to be successful. Organizations tend to retain their best employees when there is an evidence of effective succession planning and customer satisfaction [14]. Issues on employee engagement and retention may be a burgeoning problem when it is not addressed properly. This is because Malaysia holds a huge number of joint ventures and partnership with other overseas country [2] and it might be a hindrance to retain the ties between the counties. Five independent variables, which are reward and recognition, empowerment, compensation, career development, leadership are used. Whereas, Employee engagement is used as dependable variable. Job Stress acts as moderator that affect employee engagement and retention. It is hoped that this research will provide well-structured information to other authors who will be interested to analyse further in the current automobile industry in Malaysia by enhancing employee engagement level in 
workplace. Additionally, this study is illustrated to provide more insight information regarding the key drivers that influencing level of employee engagement.

\subsection{Malaysian automotive industry}

Malaysian automotive industry started in 1960 after the policy implemented by the government with the objectives to strengthen automotive industrial base and to improve Malaysian economy by not being dependent on agricultural industry [15]. The policy aims to promote Malaysian to be capable to build national cars and reduce the imports from other countries. In 1985, the first national car company, Proton has started operation and the production of first national car "Proton Saga" whereas in 1994, the second national car company Perodua was founded [3]. National Automotive Policy (NAP) was established in 2006 by the government to eliminate competition. By the year 2020, NAP envisions to position Malaysia as the leading Energy Efficient Vehicles (EEV) producer regionally. This EEV policy streamlines will in turn promote sustainable mobility, create skilled human resources and enhance technology hence contributing to the country's economy growth [1]. In 2018, more than 29,000 new jobs are anticipated to increase in the automotive workforce. More than 755,000 people is set to employ where the GDP from $4 \%$ last year will increase to 4.5\% [16]. This will provide Malaysians with new career opportunities in the Automotive industry [17].

\section{LITERATURE REVIEW AND HYPOTHESIS DEVELOPMENT}

Employee engagement is an enormously interesting concept [18]. Engagement is defined as managing employees to their work role during role performances, individual work and expressing themselves through emotional, physical, and cognitive [19],[20],[21]. An engaged employee will connect themselves to their job and co-workers and perform actively in their role without sacrificing one another. Engagement is about the inner feeling of an individual [22]. Engaged employees are psychologically present, attentive, feeling connected, integrated and having more concentration in their role performance [20],[23],[24]. Hence, willingness of employees to contribute more to the success of organization depends on the level of engagement. Moreover, engagement or disengagement is related to psychological conditions such as meaningfulness, safety and availability [19]. The job is perceived to be meaningful to the employee when they have a sense of care to their colleagues [25]. Employee engagement can be used to predict the success of an organization, outcomes of employees and financial performance [26].

Engagement is characterized by vigour, dedication and absorption [27]. Engaged employees are willing to have voluntary input, by putting discretionary effort to go extra miles in their work [28]. Engagement is also defined as employees' enthusiasm, involvement and satisfaction for their responsibilities in the organization [24],[29]. When an employee is treated well, it will affect the level of employee engagement significantly. The level of engagement brings positive and negative outcomes to the organization. According to [25] engaged employee will have high spirit to work completion and achievement of organization's objectives, vision and mission. Similarly, [24] [30] claimed that it will increase business performance, productivity and reputation of an organization. Therefore, if engaged staff feel a sense of attachment towards their organization, they are more likely to commit themselves to both their role and the organization as a whole [31].

\section{REWARD AND RECOGNITION}

Reward and recognition is defined as work or contributions employees get from the organization when they have accomplished the company goals [32]. It acts as a motivation for employees to perform better in the future [33]. Employees who are more committed to their career heavily rely on rewards [34]. Recognition is one of the most intrinsic rewards that lead to high performance and reduce employee turnover. Employees like to be praised or recognized for the job completed as a form of recognition [33] [34]. Employees who have rewarded and recognized by the company are more connected and willing to stay and strive for the company success than those who did not [35][36]. Hence, rewards must be given to employees fairly in order to attain higher level of engagement [37]

\section{EMPOWERMENT}

Empowerment gives control and power to the top management in delegating decision-making process and actions during role performance. It is employee's responsibility and availability in carrying out daily task in an organization [38].Empowerment helps to reinforce employees' capability by giving the diversity tasks and responsibilities of making business decisions that brings positive outcomes to the company [39].The psychological state of employees will be achieved when they have control over their job [19]. The employees' feeling of valuable and worthwhile in empowerment increase lead to high engagement as employees willing to perform in extra-role by giving discretionary effort [40].

\section{COMPENSATION}

Compensation is a methodical approach that provides monetary value in which employees receive for performing their jobs [41]. Compensation can greatly help an organization to become success and once employee's career objectives are achieved, they are more willing to stay and strive for the organizations [42]. When pay is increased, it has positive effects to employee engagement [43]. On the contrary, few authors claimed that increase in financial rewards is not essential to motivate lower level of employees because they prefer flexibility at work, recognition and freedom to make decision [44]. Compensation received by staff less than expected will leads to lower engagement and thus creating negative emotions at workplace [45].

\section{CAREER DEVELOPMENT}

Career development bring up work development and work adjustment of a person at every single life stage by appealing them in life planning targeted at individual's capabilities, interests, and goals with the roles at work structured by enterprises [46]. It is a series of move taken by employees within or external workplaces that facilitate personal growth, marketability and job satisfaction. It comprises of the individual actions carry out to accomplish a 
career plan. Career development involves rigorous efforts directed towards evaluating an employee's potentials, identifying possible career paths for that worker and designing and applying several forms of training to formulate that individual for more advanced work [47]. Career development enables employees to have more options in motivates employees intrinsically and results in enhanced positive employee behaviour towards work [18]. Training and career development are the determinants that influence level of employee engagement [48].

\section{LEADERSHIP}

Leaders play an important role in affecting employees' role performance and acts as a role model to the followers [49]. Therefore, they must have a strong and clear vision on what they can do to lead the followers in achieving organization performance. followers is important as it can enhance their relationship and create harmony working environment where employees are leaders' ability or behaviour and quality [50]. When the leader is engaged fully in their role performance, it will influence employees to be more engaged in their work [51]. Leaders who provide employees with trust, needs, values, and confidence at new challenges in workplace encourages employees to be passionate and committed in order to enhance employee engagement level [52]. Thus, leadership is positively correlated to employee engagement [53].

\section{RETENTION}

Employees' retention is identified as the capacity in keeping employees' relationship with the organizations. This can be related to the efforts the company exhibit to support their employees by observing the number of employees leaving and joining the organization [54]. Retention is also considered as a crucial matter as it affects to the efficiency of the business in terms of monetary and non-monetary values in one organization. It was emphasized that these employees are worth keeping as they will assist to contribute to the success of the organizations [55]. Organizations are recommended to develop and adopt retention strategies in order to build up the organizations as it would prepare them to face the challenges in dealing with employees' intention to leave or quit.

Retention strategies are actually determined by several human resource factors such as reward and recognition, career development, empowerment, compensation and leadership in one organization. These are the variables that determined the engagement of employees within the organization and it could give positive impact to their intention to remain longer in the organization [56].

\section{JOB STRESS}

Stress is normally unavoidable and portrays a negative notion that can have an impact on one's mental and physical well-being [57]. Final stage of stress leads to severe health problem which is risky to one's wellbeing [58]. Occupations throughout the world with the thermal loads and physiological consequences has limited attempts to create detailed job-exposure profiles for automotive sectors in order to choosing job that hold greater job satisfaction. It also

The good internal communication between leader and happy to work [30].A success of an organization depends on

reduce job stress for the employees. [59]. The concept of job stress has been discussed thoroughly as employees' feelings towards their job-related, mostly the feelings of worry, conflict, ambiguity of job role, work overloads and exhaustion, lead to job stress in the workplace [60].

Accentuated by [61] consistently, whenever employees have high level of job stress, the motivation, commitment and work engagement to the organizational would be declining. However, it will be inverse way for those employees who experienced less stress in their workplace. These people will have the tendency to remain in the organization as they see opportunities for them to growth within their workplace [62][63].

\section{The role of job stress as a moderator between employee engagement and retention}

Declining in the level of employee retention could be affected by the reason of job stress within the organization. Job stress provides significant influence towards employees' motivation level and performance. [64] emphasized that there is a positive correlation between job stress and intention to leave the organization. They have highlighted that those employees who experienced stress condition in the workplace might consider to have higher intentions to quit or leaving the organizations. This would lead to decrease in the retention level among the employees. When job stress affects the job satisfaction, employees will demonstrate less engagement to the organization.

A study done by [65] among the Portuguese workers, has found that job stress and engagement have a negative correlation. As the job stress level is increases, the engagement within the organization deteriorates. Similarly,[26] supported that when emotions related to the job are not in satisfactory level, employees' engagement is reduced, thus contributing to lower level of retention.

Additionally, [66] agreed that job engagement has an influence on retention level and job stress. Through the experience of high level of job stress in the organization, employees will demonstrate lack of commitment that eventually effect the engagement in the organization. Whenever the employees feel disengaged, it will contribute to a reduced retention.

In the research done among general practitioners, discussed that stress related to patients and team members has resulted in declining their work aptitude. It has led the feeling of dissatisfaction increase and eventually the intention to remain in the organization decreases [67]. Besides, job stress may also create problems in the organizational and individual level in an organization where it impacts employee commitment and engagement eventually [68]. This is supported by [69] where high level of stress will lead to low level of employee engagement. In conclusion, based on the discussions above. The current study intends to examine the role of job stress towards the employee engagement and retention.

\section{Employee Engagement and Retention}

Numerous researches till this date has emphasize the relationship of retention with job stress, motivation and commitment that could impact the organization [70]. 
Significant research work done by several researchers reveal that employee engagement has a positive relationship with retention. It was emphasized the employees' commitment in the organization eventually leads to anticipated retention level and positive impact to the profitability of the business [26].

A study conducted by [71][72] demonstrates that the intention to leave the organizations among nurses are due to the low level of engagement (lack of empowerment). In addition, employees who exhibit encouraging attitude towards the organizations are employees who have high level of engagement. Employees who demonstrates high level of engagement tend to have high intention to stay longer in the organization. Past research depicts employee engagement has reverse relationship with intention to leave. Employees that have sense of engagement in their workplace will have low tendency to leave the organization as they think it provides the chance to develop themselves [66]. It was found that employee engagement influences retention level among among property employees in U.S[73]. Moreover, employee engagement is greatly influenced by the existing company culture that would directly influence employee engagement and retention [74]. [75] argued that when employees hardwork and expectations are not compensated with rewards, it would lead to low employee engagement, hence retaining employees would be a difficult task as they may have a feeling to move to a better working environment. In this notion, it can be concluded that engagement will have an impact on retention in the organization.

H1: Rewards and recognition will be positively related to employee engagement.

H2: Leadership will be positively related to employee engagement.

H3: Compensation will be positively related to employee engagement

H4: Empowerment will be positively related to employee engagement.

H5: Career Development will be positively related to employee engagement

H6: Employee engagement will be positively related to employee retention

H7: Job stress will moderate between employee engagement and retention

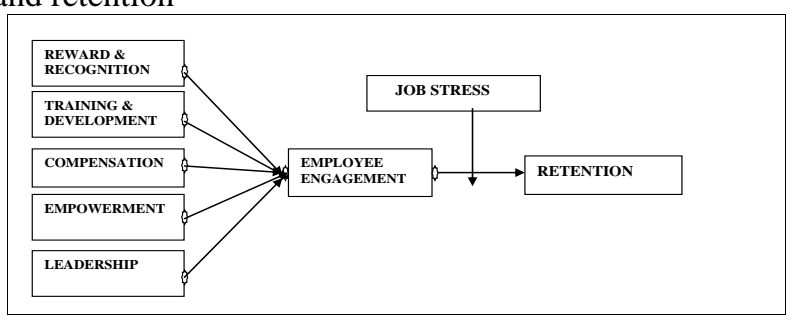

Figure 1: Theoretical Framework

\section{METHODOLOGY}

Sample were drawn from the employees of automotive industry in Malaysia. The target respondents are technicians in different level of education, experience, gender, age, race, nationality, marital status and income. The survey was conducted in Selangor because it holds a high number of job creations with more than $70 \%$ in the automotive industry [76]. Convenience sampling was used and a total of 342

questionnaires were distributed and 288 responses collected, yielding a response rate of $84 \%$. Questionnaires were measured. $88 \%$ of respondents were male. The marital status of the employees was married (92\%), $8 \%$ were single. Age category has been distributed with three levels among which $71 \%$ of employees are 35 to 45 years old. All variables were adopted and measured using multiple items from previous studies. Questionnaires were rated using five-point Likert scales ranging from strongly agree to disagree that have demonstrated to be substantial and dependable in past examinations. A structural equation modeling technique (SPSS AMOS v22) has been used to identify the relationship between the endogenous, exogenous and mediating variables. Convergent validity was tested for employee engagement.

\section{RESULTS}

\section{SCALE VALIDITY}

Scale validity is conducted through confirmatory factor analysis. The latent variables are correlated in order to identify the validity and reliability of the constructs. The constructs are confirmed for its convergence with the items and discrimination with the items of the other constructs.

$\mathrm{Ha}$ - The model has a good fit.

\section{Figure 2: The confirmatory factor analysis}

From the model fit outline, it uncovers that the fit measures demonstrated the basic model was worthy. Alongside the model's general fit, its parameters were tried to choose

whether to acknowledge the proposed connections among exogenous and endogamous constructs [77]. This model has solid match. So, it tends to be inferred that the scale is recommendable for further examination and this outcome is highly reliable. 
Table.1: Model fit Summary- CFA

\begin{tabular}{|c|c|c|c|c|c|}
\hline Model & NPAR & CMIN & DF & $\mathbf{P}$ & $\begin{array}{l}\text { CMIN } \\
\text { /DF }\end{array}$ \\
\hline $\begin{array}{l}\text { Default } \\
\text { model }\end{array}$ & 93 & 1977.2 & 403 & .0 & 4.906 \\
\hline $\begin{array}{l}\text { Saturate } \\
\mathrm{d} \text { model }\end{array}$ & 496 & .000 & 0 & & \\
\hline $\begin{array}{l}\text { Indepen } \\
\text { dence } \\
\text { model }\end{array}$ & 31 & 5048.5 & 465 & .0 & 10.857 \\
\hline Model & RMR & GFI & $\begin{array}{l}\text { AGF } \\
\text { I }\end{array}$ & PGFI & RMSEA \\
\hline $\begin{array}{l}\text { Default } \\
\text { model }\end{array}$ & .073 & .92 & .911 & .589 & .071 \\
\hline $\begin{array}{l}\text { Saturate } \\
\text { d model }\end{array}$ & .000 & 1 & & & \\
\hline $\begin{array}{l}\text { Indepen } \\
\text { dence } \\
\text { model }\end{array}$ & .235 & .26 & .220 & .252 & .085 \\
\hline
\end{tabular}

\section{Average Variance Extracted}

A reliable construct has an AVE of 0.5 or higher as sufficient convergent validity. An AVE of less than .5 denotes an average, and less valid instrument. In Table.2, The AVE of variables in the constructs are more than 0.5 which reveals a reliable group of variables in the respective constructs.

Table No.2 Construct Reliability

\begin{tabular}{|c|c|c|c|c|c|c|}
\hline $\begin{array}{l}\text { Va } \\
\text { ria } \\
\text { ble } \\
\text { S }\end{array}$ & $\begin{array}{l}\text { Constr } \\
\text { ucts }\end{array}$ & $\begin{array}{l}\text { Estim } \\
\text { ate }\end{array}$ & $\begin{array}{l}\text { Item } \\
\text { reliabi } \\
\text { lity }\end{array}$ & $\begin{array}{l}\text { Delta } \\
= \\
1- \\
\text { item } \\
\text { reliab } \\
\text { ility }\end{array}$ & $\begin{array}{l}\text { AVE } \\
\text { (Aver } \\
\text { age } \\
\text { Varia } \\
\text { nce } \\
\text { Extra } \\
\text { cted) }\end{array}$ & $\begin{array}{l}\text { Con } \\
\text { stru } \\
\text { ct } \\
\text { Reli } \\
\text { abili } \\
\text { ty }\end{array}$ \\
\hline $\begin{array}{l}\mathrm{RR} \\
3\end{array}$ & $\begin{array}{l}\text { Rewar } \\
\text { ds \& } \\
\text { Recog } \\
\text { nition }\end{array}$ & 0.702 & $\begin{array}{l}0.4928 \\
04\end{array}$ & $\begin{array}{l}0.507 \\
196\end{array}$ & \multirow{3}{*}{0.527} & \multirow{3}{*}{$\begin{array}{l}0.76 \\
9\end{array}$} \\
\hline $\begin{array}{l}\mathrm{RR} \\
2\end{array}$ & $\begin{array}{l}\text { Rewar } \\
\text { ds \& } \\
\text { Recog } \\
\text { nition }\end{array}$ & 0.666 & $\begin{array}{l}0.4435 \\
56\end{array}$ & $\begin{array}{l}0.556 \\
444\end{array}$ & & \\
\hline $\begin{array}{l}\mathrm{RR} \\
1\end{array}$ & $\begin{array}{l}\text { Rewar } \\
\text { ds \& } \\
\text { Recog } \\
\text { nition }\end{array}$ & 0.803 & $\begin{array}{l}0.6448 \\
09\end{array}$ & $\begin{array}{l}0.355 \\
191\end{array}$ & & \\
\hline L4 & $\begin{array}{l}\text { Leader } \\
\text { ship }\end{array}$ & 0.669 & $\begin{array}{l}0.4475 \\
61\end{array}$ & $\begin{array}{l}0.552 \\
439\end{array}$ & \multirow{4}{*}{0.632} & \multirow{4}{*}{$\begin{array}{l}0.87 \\
1\end{array}$} \\
\hline L3 & $\begin{array}{l}\text { Leader } \\
\text { ship }\end{array}$ & 0.706 & $\begin{array}{l}0.4984 \\
36\end{array}$ & $\begin{array}{l}0.501 \\
564\end{array}$ & & \\
\hline L2 & $\begin{array}{l}\text { Leader } \\
\text { ship }\end{array}$ & 0.912 & $\begin{array}{l}0.8317 \\
44\end{array}$ & $\begin{array}{l}0.168 \\
256\end{array}$ & & \\
\hline L1 & $\begin{array}{l}\text { Leader } \\
\text { ship }\end{array}$ & 0.866 & $\begin{array}{l}0.7499 \\
56\end{array}$ & $\begin{array}{l}0.250 \\
044\end{array}$ & & \\
\hline $\begin{array}{l}\text { Em } \\
4\end{array}$ & $\begin{array}{l}\text { Empo } \\
\text { werme } \\
\text { nt }\end{array}$ & 0.752 & $\begin{array}{l}0.5655 \\
04\end{array}$ & $\begin{array}{l}0.434 \\
496\end{array}$ & \multirow[t]{2}{*}{0.54} & \multirow{2}{*}{$\begin{array}{l}0.82 \\
3\end{array}$} \\
\hline $\begin{array}{l}\text { Em } \\
3\end{array}$ & $\begin{array}{l}\text { Empo } \\
\text { werme }\end{array}$ & 0.639 & $\begin{array}{l}0.4083 \\
21\end{array}$ & $\begin{array}{l}0.591 \\
679\end{array}$ & & \\
\hline
\end{tabular}

\begin{tabular}{|c|c|c|c|c|c|c|}
\hline & $\mathrm{nt}$ & & & & & \\
\hline $\begin{array}{l}\text { Em } \\
2\end{array}$ & $\begin{array}{l}\text { Empo } \\
\text { werme } \\
\text { nt }\end{array}$ & 0.778 & $\begin{array}{l}0.6052 \\
84 \\
\end{array}$ & $\begin{array}{l}0.394 \\
716\end{array}$ & & \\
\hline $\begin{array}{l}\text { Em } \\
1\end{array}$ & $\begin{array}{l}\text { Empo } \\
\text { werme } \\
\text { nt }\end{array}$ & 0.761 & $\begin{array}{l}0.5791 \\
21\end{array}$ & $\begin{array}{l}0.420 \\
879\end{array}$ & & \\
\hline C3 & $\begin{array}{l}\text { Compe } \\
\text { nsation }\end{array}$ & 0.749 & $\begin{array}{l}0.5610 \\
01\end{array}$ & $\begin{array}{l}0.438 \\
999\end{array}$ & \multirow{3}{*}{0.608} & \multirow{3}{*}{$\begin{array}{l}0.82 \\
1\end{array}$} \\
\hline $\mathrm{C} 2$ & $\begin{array}{l}\text { Compe } \\
\text { nsation }\end{array}$ & 0.675 & $\begin{array}{l}0.4556 \\
25\end{array}$ & $\begin{array}{l}0.544 \\
375\end{array}$ & & \\
\hline $\mathrm{C} 1$ & $\begin{array}{l}\text { Compe } \\
\text { nsation }\end{array}$ & 0.899 & $\begin{array}{l}0.8082 \\
01\end{array}$ & $\begin{array}{l}0.191 \\
799\end{array}$ & & \\
\hline $\begin{array}{l}\mathrm{CD} \\
3\end{array}$ & $\begin{array}{l}\text { Career } \\
\& \\
\text { Develo } \\
\text { pment }\end{array}$ & 0.771 & $\begin{array}{l}0.5944 \\
41\end{array}$ & $\begin{array}{l}0.405 \\
559\end{array}$ & \multirow{3}{*}{0.599} & \multirow{3}{*}{$\begin{array}{l}0.81 \\
7\end{array}$} \\
\hline $\begin{array}{l}\mathrm{CD} \\
2\end{array}$ & $\begin{array}{l}\text { Career } \\
\& \\
\text { Develo } \\
\text { pment }\end{array}$ & 0.815 & $\begin{array}{l}0.6642 \\
25\end{array}$ & $\begin{array}{l}0.335 \\
775\end{array}$ & & \\
\hline $\begin{array}{l}\text { CD } \\
1\end{array}$ & $\begin{array}{l}\text { Career } \\
\& \\
\text { Develo } \\
\text { pment }\end{array}$ & 0.734 & $\begin{array}{l}0.5387 \\
56\end{array}$ & $\begin{array}{l}0.461 \\
244\end{array}$ & & \\
\hline $\begin{array}{l}\mathrm{EE} \\
1\end{array}$ & $\begin{array}{l}\text { Emplo } \\
\text { yee } \\
\text { Engage } \\
\text { ment }\end{array}$ & 0.873 & $\begin{array}{l}0.7621 \\
29\end{array}$ & $\begin{array}{l}0.237 \\
871\end{array}$ & \multirow{5}{*}{0.503} & \multirow{5}{*}{$\begin{array}{l}0.82 \\
9\end{array}$} \\
\hline $\begin{array}{l}\mathrm{EE} \\
2\end{array}$ & $\begin{array}{l}\text { Emplo } \\
\text { yee } \\
\text { Engage } \\
\text { ment }\end{array}$ & 0.612 & $\begin{array}{l}0.3745 \\
44\end{array}$ & $\begin{array}{l}0.625 \\
456\end{array}$ & & \\
\hline $\begin{array}{l}\mathrm{EE} \\
3\end{array}$ & $\begin{array}{l}\text { Emplo } \\
\text { yee } \\
\text { Engage } \\
\text { ment }\end{array}$ & 0.516 & $\begin{array}{l}0.2662 \\
56\end{array}$ & $\begin{array}{l}0.733 \\
744\end{array}$ & & \\
\hline $\begin{array}{l}\mathrm{EE} \\
4\end{array}$ & $\begin{array}{l}\text { Emplo } \\
\text { yee } \\
\text { Engage } \\
\text { ment }\end{array}$ & 0.615 & $\begin{array}{l}0.3782 \\
25\end{array}$ & $\begin{array}{l}0.621 \\
775\end{array}$ & & \\
\hline $\begin{array}{l}\mathrm{EE} \\
5\end{array}$ & $\begin{array}{l}\text { Emplo } \\
\text { yee } \\
\text { Engage } \\
\text { ment }\end{array}$ & 0.856 & $\begin{array}{l}0.7327 \\
36\end{array}$ & $\begin{array}{l}0.267 \\
264\end{array}$ & & \\
\hline JS1 & $\begin{array}{l}\text { Job } \\
\text { Stress }\end{array}$ & 0.834 & $\begin{array}{l}0.6955 \\
56\end{array}$ & $\begin{array}{l}0.304 \\
444\end{array}$ & \multirow{4}{*}{0.649} & \multirow{4}{*}{0.88} \\
\hline JS2 & $\begin{array}{l}\text { Job } \\
\text { Stress }\end{array}$ & 0.848 & $\begin{array}{l}0.7191 \\
04\end{array}$ & $\begin{array}{l}0.280 \\
896\end{array}$ & & \\
\hline JS3 & $\begin{array}{l}\text { Job } \\
\text { Stress }\end{array}$ & 0.853 & $\begin{array}{l}0.7276 \\
09\end{array}$ & $\begin{array}{l}0.272 \\
391\end{array}$ & & \\
\hline JS4 & $\begin{array}{l}\text { Job } \\
\text { Stress }\end{array}$ & 0.674 & $\begin{array}{l}0.4542 \\
76\end{array}$ & $\begin{array}{l}0.545 \\
724\end{array}$ & & \\
\hline $\mathrm{R} 1$ & $\begin{array}{l}\text { Retenti } \\
\text { on }\end{array}$ & 0.684 & $\begin{array}{l}0.4678 \\
56\end{array}$ & $\begin{array}{l}0.532 \\
144\end{array}$ & \multirow{2}{*}{0.609} & \multirow{2}{*}{$\begin{array}{l}0.88 \\
5\end{array}$} \\
\hline $\mathrm{R} 2$ & $\begin{array}{l}\text { Retenti } \\
\text { on }\end{array}$ & 0.886 & $\begin{array}{l}0.7849 \\
96\end{array}$ & $\begin{array}{l}0.215 \\
004\end{array}$ & & \\
\hline
\end{tabular}




\begin{tabular}{|l|l|l|l|l|l|l|}
\hline R3 & $\begin{array}{l}\text { Retenti } \\
\text { on }\end{array}$ & 0.715 & $\begin{array}{l}0.5112 \\
25\end{array}$ & $\begin{array}{l}0.488 \\
775\end{array}$ & \multirow{4}{*}{} & \\
\cline { 1 - 5 } R4 & $\begin{array}{l}\text { Retenti } \\
\text { on }\end{array}$ & 0.746 & $\begin{array}{l}0.5565 \\
16\end{array}$ & $\begin{array}{l}0.443 \\
484\end{array}$ & & \\
\cline { 1 - 4 } R5 & $\begin{array}{l}\text { Retenti } \\
\text { on }\end{array}$ & 0.851 & $\begin{array}{l}0.7242 \\
01\end{array}$ & $\begin{array}{l}0.275 \\
799\end{array}$ & & \\
\hline
\end{tabular}

\section{Construct Reliability}

Construct reliability estimate needs to be higher than .7 for a good reliable instrument. The acceptable scale would be between .6 and .7. 1[78]. A good internal consistency is assumed when construct reliability score is high. From the table.2, the construct reliability is more than .7. Therefore, it denotes high construct reliability. The model seems to have a recommendable fit with the $\mathrm{CMIN} / \mathrm{DF}=4.113$, GFI=.875, $\mathrm{AGFI}=.721$, RMSEA $=0.104$ as suggested by [79].

Figure 3: Structural Equation Model

Table 3: Model Summary

\begin{tabular}{|c|c|c|c|c|c|}
\hline Model & $\begin{array}{l}\text { NPA } \\
\mathbf{R}\end{array}$ & CMIN & DF & $\mathbf{P}$ & $\begin{array}{l}\text { CMIN } \\
\text { /DF }\end{array}$ \\
\hline $\begin{array}{l}\text { Default } \\
\text { model }\end{array}$ & 73 & $\begin{array}{l}1254.5 \\
81\end{array}$ & 305 & $\begin{array}{l}.0 \\
00\end{array}$ & 4.113 \\
\hline $\begin{array}{l}\text { Saturated } \\
\text { model }\end{array}$ & 378 & .000 & 0 & & \\
\hline $\begin{array}{l}\text { Independenc } \\
\text { e model }\end{array}$ & 27 & $\begin{array}{l}3849.5 \\
23 \\
\end{array}$ & 351 & $\begin{array}{l}.0 \\
00 \\
\end{array}$ & 10.967 \\
\hline Model & $\begin{array}{l}\mathbf{R M} \\
\mathbf{R}\end{array}$ & GFI & $\begin{array}{l}\text { AG } \\
\text { FI }\end{array}$ & $\begin{array}{l}\mathbf{P} \\
\mathbf{G} \\
\mathbf{F I}\end{array}$ & RMSEA \\
\hline $\begin{array}{l}\text { Default } \\
\text { model }\end{array}$ & .066 & .875 & .721 & $\begin{array}{l}.6 \\
25\end{array}$ & .104 \\
\hline $\begin{array}{l}\text { Saturated } \\
\text { model }\end{array}$ & .000 & 1.000 & & & \\
\hline $\begin{array}{l}\text { Independenc } \\
\text { e model }\end{array}$ & .237 & .296 & .241 & $\begin{array}{l}.2 \\
75\end{array}$ & .186 \\
\hline
\end{tabular}

\section{REGRESSION WEIGHTS: (RETENTION - DEFAULT MODEL)}

\begin{tabular}{|l|l|l|l|l|l|}
\hline $\begin{array}{l}\text { Independ } \\
\text { ent } \\
\text { variables }\end{array}$ & $\begin{array}{l}\text { Dependent } \\
\text { variables }\end{array}$ & $\begin{array}{l}\text { Est } \\
\text { ima } \\
\text { te }\end{array}$ & S.E. & C.R. & P \\
\hline $\begin{array}{l}\text { Employee } \\
\text { engagement }\end{array}$ & $\begin{array}{l}\text { Career \& } \\
\text { Development }\end{array}$ & $\begin{array}{l}.59 \\
9\end{array}$ & $\begin{array}{l}.22 \\
3\end{array}$ & $\begin{array}{l}2.68 \\
7\end{array}$ & $\begin{array}{l}.00 \\
7\end{array}$ \\
\hline $\begin{array}{l}\text { Employee } \\
\text { engagement }\end{array}$ & $\begin{array}{l}\text { Empowerme } \\
\mathrm{nt}\end{array}$ & $\begin{array}{l}.44 \\
0\end{array}$ & $\begin{array}{l}.41 \\
4\end{array}$ & .366 & $\begin{array}{l}.01 \\
4\end{array}$ \\
\hline $\begin{array}{l}\text { Employee } \\
\text { engagement }\end{array}$ & Leadership & $\begin{array}{l}.18 \\
1\end{array}$ & $\begin{array}{l}.47 \\
9\end{array}$ & .337 & $\begin{array}{l}.03 \\
6\end{array}$ \\
\hline $\begin{array}{l}\text { Employee } \\
\text { engagement }\end{array}$ & $\begin{array}{l}\text { Rewards \& } \\
\text { Recognition }\end{array}$ & $\begin{array}{l}.01 \\
6\end{array}$ & $\begin{array}{l}.33 \\
7\end{array}$ & .048 & $\begin{array}{l}.96 \\
2\end{array}$ \\
\hline $\begin{array}{l}\text { Employee } \\
\text { engagement }\end{array}$ & $\begin{array}{l}\text { Compensatio } \\
\mathrm{n}\end{array}$ & $\begin{array}{l}-.00 \\
5\end{array}$ & $\begin{array}{l}.23 \\
7\end{array}$ & -.021 & $\begin{array}{l}.98 \\
4\end{array}$ \\
\hline Retention & $\begin{array}{l}\text { Employee } \\
\text { engagement }\end{array}$ & $\begin{array}{l}.81 \\
2\end{array}$ & $\begin{array}{l}.09 \\
0\end{array}$ & $\begin{array}{l}8.99 \\
1\end{array}$ & $* * *$ \\
\hline
\end{tabular}

\section{HYPOTHESIS}

H1: Rewards and recognition will be positively related to employee engagement.

The relationship between the Rewards and recognition and employee engagement is not statistically significant with a regression coefficient of $.016(\mathrm{P}<.962)$. There is no sufficient variance explained for this relationship. This relationship is not predicted with the selected sample.

It was said that it will create an unhealthy competition between the employees as some employees may even go further to be getting a reward and recognition, thus leading them to have a bad health issues, for instance stress, depression and etc. The regression coefficients of the model for all the path shows a significant relationship between the variables except the Rewards \& recognition and compensation on employee engagement. The other determinants of employee engagement are significantly predicted. The relationship between all measured variables and the latent variable show significant relationships Therefore, the employee is not being able to be engaged in their work. Employees may even go further to actually harm the organization in order to have an increase in rewards and to be recognized by the company. It also has a negative relationship towards employee engagement as it has the cause of biases. It is where biases happen and only certain employees that would receive rewards and be recognize by the employer. Thus, this will create a sense of dissatisfaction that will reduce the engagement level of the employees in their job. [80]

H2: Leadership will be positively related to employee engagement.

The relationship between the leadership and employee engagement is statistically significant with a regression coefficient of .181 $(\mathrm{P}>.036)$ the alternate hypothesis as formulated is accepted. The Leadership influence the employee engagement positively. This indicates that a positive approach in the leadership increases by 1 unit the employee engagement would enhance by .18 units. This finding is in line with the previous studies where researchers found 
positive relationship between leadership and engagement [53]. In order to motivate employees, leaders must have a clear influence on employees by showing clear values and encouragement. Thus, leaders have a good influential role in employee engagement.

\section{H3: Compensation will be positively related to employee engagement}

The relationship between the Compensation and employee engagement is not statistically significant with a regression coefficient of -.005 $(\mathrm{P}<.984)$. There is no sufficient variance explained for this relationship. This relationship is not predicted with the selected sample. This study found that compensation is not positively related with employee engagement. This could be due to certain circumstances where financial rewards of the organization system require the organization to deduct a large sum of money that could leave some employees in dilemma due to insufficient of money which could lead to low engagement.Besides, it could also be because of the inadequate salary employees receive in comparison to all their effort and responsibilities in performing their job.. For the employee to be engage in their task, therefore compensation needs to in a fair manner to the employees as it will be competent for the employees and also gain potential employees in the organization.

\section{H4: Empowerment will be positively related to employee engagement.}

The relationship between the Empowerment and employee engagement is statistically significant with a regression coefficient of $.44(\mathrm{P}<.014)$ the alternate hypothesis as formulated is accepted. The empowerment influences positively the employee engagement. The regression coefficient value .44 denotes that there is a positive .44 unit hike when there is a 1 unit hike. Empowerment has a positive relationship with employee engagement as when employees are being empowered, therefore it would increase their employee engagement in the organization as the employees are able to perform their task well where their productivity level will be increasing at the same time. Thus it can be concluded that an empowered employee will be more engaged when a task is given.

\section{H5: Career Development will be positively related to employee engagement.}

The relationship between the career development and employee retention is statistically significant with a regression coefficient of $.599(\mathrm{P}<.007)$ the alternate hypothesis as formulated is accepted. The career development has a positive impact on the retention and it is clear from the regression coefficient of .599-unit enhancement when there is 1-unit enhancement occur. Career development enables employees to have more options in choosing job that hold greater job satisfaction. It also motivates employees intrinsically and results in enhanced positive employee behavior towards work [18]. Training and career development are the determinants that influence level of employee engagement [48]. Employee engagement level increase when employees feel that they are able to contribute to the organization success through their skills and ability. Career development will also not only retain them but also motivate and recognize them beside career development increases the employee engagement. In order for the employer to develop career development plans with their employees will be through meeting them per individual to know more about the areas that they want to improve and their talents.

\section{H6: Employee engagement will be positively related to employee retention}

The relationship between the employee engagement and retention is statistically significant with a regression coefficient of $.812(\mathrm{P}<.000)$ the alternate hypothesis as formulated is accepted. The empowerment influences positively the employee engagement. The regression coefficient value denotes that there is .812 unit increase when there is a 1 unit increase. Employee engagement is a main key business that influences retention. When employees are involved and motivated in their job, it leads them to retain in the organization. Thus, this study is in line with [81] where retention is ameliorated with employee engagement.

\section{Moderation effect}

A structural equation model is conducted in order to identify the relationship between the constructs and the factors of retention model. A multi group moderation test is done to check the moderation effect for the two groups low job stress and high job stress. Two hypothesis is formulated

\section{H7: Job stress will moderate retention model}

$\mathrm{H7a}$ : High job stress has a moderating effect

H7b: Low job stress has a moderating effect

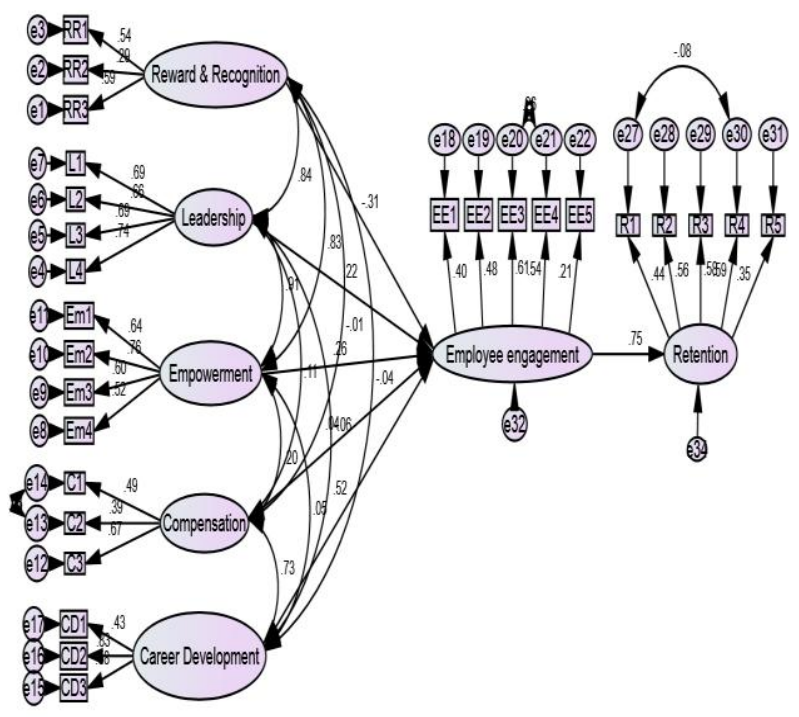

Figure 4: The moderating effect on the retention model on high job stress 


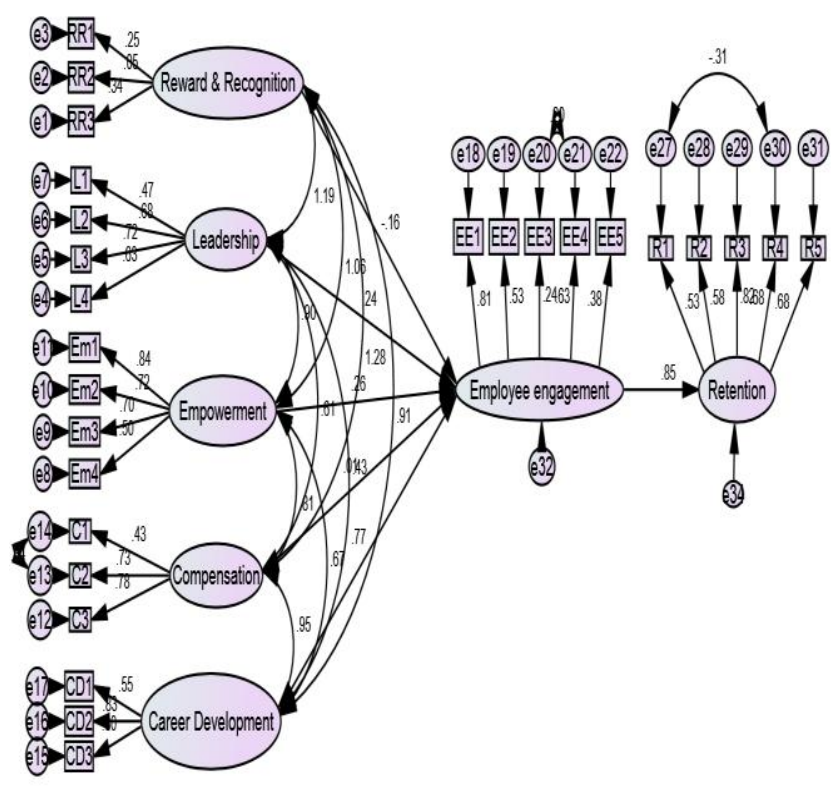

Figure 5: The moderating effect on the retention model on low job stress

Table 4: Model summary

\begin{tabular}{|c|c|c|c|c|c|}
\hline Model & $\begin{array}{l}\text { NPA } \\
\mathbf{R}\end{array}$ & CMIN & DF & $\mathbf{P}$ & $\begin{array}{l}\text { CMI } \\
\text { N/DF }\end{array}$ \\
\hline $\begin{array}{l}\text { Default } \\
\text { model }\end{array}$ & 146 & $\begin{array}{l}1802.6 \\
10\end{array}$ & 610 & $\begin{array}{l}.00 \\
0\end{array}$ & 2.955 \\
\hline $\begin{array}{l}\text { Saturated } \\
\text { model }\end{array}$ & 756 & .000 & 0 & & \\
\hline $\begin{array}{l}\text { Independe } \\
\text { nce model }\end{array}$ & 54 & $\begin{array}{l}3856.7 \\
34\end{array}$ & 702 & $\begin{array}{l}.00 \\
0\end{array}$ & 5.494 \\
\hline Model & $\begin{array}{l}\mathbf{R M} \\
\mathbf{R}\end{array}$ & GFI & $\begin{array}{l}\text { AGF } \\
\text { I }\end{array}$ & $\begin{array}{l}\mathbf{P} \\
\mathbf{G} \\
\mathbf{F I} \\
\end{array}$ & $A^{\text {RMSE }}$ \\
\hline $\begin{array}{l}\text { Default } \\
\text { model }\end{array}$ & .073 & .914 & .846 & $\begin{array}{l}.77 \\
6\end{array}$ & .083 \\
\hline $\begin{array}{l}\text { Saturated } \\
\text { model }\end{array}$ & .000 & 1.000 & & & \\
\hline $\begin{array}{l}\text { Independe } \\
\text { nce model }\end{array}$ & .218 & .357 & .308 & $\begin{array}{l}.33 \\
2\end{array}$ & .125 \\
\hline
\end{tabular}

The model fit indices show a good fit GFI $=.914$, AGFI=.846, $\mathrm{RMSEA}=.083$. The relationship between the variables show a significant relationship. The job stress has been standardized and a K-means clustering were adopted to classify as low and high categories with mean centroid method. The retention model shows a significant different between the high and low category job stress. The job stress moderates the retention model.

Table .5: Moderating Effect Of Job Stress With Low And High Job Stress

\begin{tabular}{|c|c|c|c|c|c|}
\hline \multicolumn{2}{|c|}{$\begin{array}{l}\text { Regression Weights: (Low } \\
\text { Job stress) }\end{array}$} & \multirow{2}{*}{$\begin{array}{l}\text { Esti } \\
\text { mat } \\
\text { e } \\
-0.3 \\
59\end{array}$} & \multirow{2}{*}{$\begin{array}{l}\text { S.E. } \\
0.32 \\
9\end{array}$} & \multirow{2}{*}{$\begin{array}{l}\text { C.R. } \\
-1.092\end{array}$} & \multirow{2}{*}{$\begin{array}{l}\text { null hypothesis is accepted for the relationships rewards \& } \\
\mathbf{P} \text { recognition and employee engagement } .68(\mathrm{P}<.301) \text {, } \\
\text { Compensation and employee engagement } .37(\mathrm{P}<.63) \text {. These } \\
\text { tw } \phi \text { relationships are not significant. }\end{array}$} \\
\hline $\begin{array}{l}\text { Employee } \\
\text { Engagement }\end{array}$ & $\begin{array}{l}\text { Career and } \\
\text { Development }\end{array}$ & & & & \\
\hline $\begin{array}{l}\text { Employee } \\
\text { Engagement }\end{array}$ & $\begin{array}{l}\text { Empowermen } \\
\mathrm{t}\end{array}$ & $\begin{array}{l}0.00 \\
8\end{array}$ & $\begin{array}{l}0.65 \\
4\end{array}$ & 0.012 & $\begin{array}{l}\text { The study clearly demonstrates that the respondents } \\
\text { provides importance to the intrinsic factors like Leadership, }\end{array}$ \\
\hline $\begin{array}{l}\text { Employee } \\
\text { Engagement }\end{array}$ & Leadership & $\begin{array}{l}0.30 \\
8\end{array}$ & $\begin{array}{l}0.64 \\
3\end{array}$ & 0.479 & $\begin{array}{l}\text { Empowerment and career } \\
0.03 \text { teyelopment and rewards \& }\end{array}$ \\
\hline $\begin{array}{l}\text { etrieval Number: } \\
\text { OI: } 10.35940 / \text { ijec }\end{array}$ & $\begin{array}{l}1080986 S 319 / 20 \\
1108.0986 S 319\end{array}$ & BEIE & & & $\begin{array}{l}\text { Published By: } \\
\text { Blue Eyes Intelligence Engin } \\
\& \text { Sciences Publication }\end{array}$ \\
\hline
\end{tabular}

\begin{tabular}{|l|l|l|l|l|l|}
$\begin{array}{l}\text { Employee } \\
\text { Engagement }\end{array}$ & $\begin{array}{l}\text { Rewards \& } \\
\text { Recognition }\end{array}$ & 0.68 & $\begin{array}{l}0.65 \\
7\end{array}$ & 1.035 & 0.301 \\
\hline $\begin{array}{l}\text { Employee } \\
\text { Engagement }\end{array}$ & $\begin{array}{l}\text { Compensatio } \\
\mathrm{n}\end{array}$ & 0.37 & $\begin{array}{l}0.76 \\
7\end{array}$ & 0.482 & 0.63 \\
\hline Retention & $\begin{array}{l}\text { Employee } \\
\text { Engagement }\end{array}$ & $\begin{array}{l}0.55 \\
6\end{array}$ & $\begin{array}{l}0.10 \\
5\end{array}$ & 5.311 & $* * *$ \\
\hline $\begin{array}{l}\text { Regression } \\
\text { Job stress) }\end{array}$ & Weights: (High & $\begin{array}{l}\text { Esti } \\
\text { mat } \\
\text { e }\end{array}$ & S.E. & C.R. & P \\
\hline $\begin{array}{l}\text { Employee } \\
\text { Engagement }\end{array}$ & $\begin{array}{l}\text { Career and } \\
\text { Development }\end{array}$ & $\begin{array}{l}0.30 \\
3\end{array}$ & $\begin{array}{l}0.17 \\
2\end{array}$ & 1.765 & 0.038 \\
\hline $\begin{array}{l}\text { Employee } \\
\text { Engagement }\end{array}$ & $\begin{array}{l}\text { Empowermen } \\
\text { t }\end{array}$ & $\begin{array}{l}0.12 \\
6\end{array}$ & $\begin{array}{l}0.26 \\
1\end{array}$ & 0.481 & $* * *$ \\
\hline $\begin{array}{l}\text { Employee } \\
\text { Engagement }\end{array}$ & Leadership & $\begin{array}{l}-0.1 \\
16\end{array}$ & $\begin{array}{l}0.18 \\
8\end{array}$ & -0.617 & $* * *$ \\
\hline $\begin{array}{l}\text { Employee } \\
\text { Engagement }\end{array}$ & $\begin{array}{l}\text { Rewards \& } \\
\text { Recognition }\end{array}$ & $\begin{array}{l}0.08 \\
3\end{array}$ & $\begin{array}{l}0.19 \\
6\end{array}$ & 0.422 & 0.673 \\
\hline $\begin{array}{l}\text { Employee } \\
\text { Engagement }\end{array}$ & $\begin{array}{l}\text { Compensatio } \\
\mathrm{n}\end{array}$ & 0.02 & $\begin{array}{l}0.14 \\
4\end{array}$ & 0.136 & 0.891 \\
\hline Retention & $\begin{array}{l}\text { Employee } \\
\text { Engagement }\end{array}$ & $\begin{array}{l}0.86 \\
8\end{array}$ & $\begin{array}{l}0.27 \\
7\end{array}$ & 3.137 & 0.002 \\
\hline
\end{tabular}

The table 4, depicts the moderating effect of job stress significantly. It reveals that the Leadership, Rewards \& Recognition, Compensation, Employee Engagement are related with retention sequentially. The multi group moderation classify the respondents with two sub groups with the cluster centroid method. The low job stress consists of 119 respondents and high job stress category consists of 169 respondents.

\section{H7a : High job stress has a moderating effect}

The output of multi group moderation shows that the influence of employee engagement on retention (.868, $\mathrm{p}<0.05)$ is low when the job stress is high. The alternative hypothesis is accepted since the model shows the significance among the empowerment and employee engagement.0.126 ( $\mathrm{P}$ $>$.000). The Career and Development and employee engagement .303 ( $\mathrm{P}>.038)$. Leadership and employee engagement $.308(\mathrm{P}>.032)$. The null hypothesis is accepted for the relationships rewards \& recognition and employee engagement .083( $\mathrm{P}<.673)$, Compensation and employee engagement $.02(\mathrm{P}<.891)$. These two relationships are not significant.

\section{H7b: Low job stress has a moderating effect}

The relationship between the employee engagement and retention $(.556, \mathrm{P}>0.000)$ is influenced highly when the job stress is low. The alternative hypothesis is accepted since the model shows the significance among the empowerment and employee engagement.008 ( $\mathrm{P}>.000)$. The Career and Development and employee engagement -0.359 ( $\mathrm{P}>.025)$. Leadership and employee engagement .308 ( $\mathrm{P}>.032)$. The recognition and employee engagement .68(P<.301), 
recognition, compensation are not statistically explained. So the study reveals that the employee engagement is influenced by the intrinsic factors. Further to that, employee engagement would positively impact the retention. Eventually, The Malaysian automotive industry needs an environment where the employee engagement is effective through providing the better leadership, and the employee empowerment and career developments can be given weightage and visible to the employees. This would improve the level of retention of employees.

\section{CONCLUSION}

The automotive industry in Malaysia plays a huge role in the country's economy. However, employees play a vital role as they are the backbone in helping the company to grow and prosper. It is important for the employee to be engaged in their work in order to be able to help to produce quality service and product that not only will help them to retain their customers but at the same time to be able to make the organization to increase profit. Employee engagement also goes well with employee retention. It is because in order for an organization in the automotive industry to retain the employees therefore they are supposed to make sure their employees are engaged. Where the organization are supposed to find ways and strategies that are able to develop to help the employees so that they will be engaged in the organization to increase the productivity level. Job stress plays a role as a moderator in the organization between employee engagement and employee retention. Job stress may be in the form of responsibilities, workload, climate or et that may have an affect towards the employee wellbeing in terms of physical and mental. When employees are affected with job stress therefore it will reduce their engagement level in the organization that will have an affect towards the retention of the employees. Thus in this research, the employee engagement plays a big role towards the automotive industry as good engaged employees will be able to help the organization to grow and at the same tie to produce quality product to be able to retain their customers but also at the same time it will increase the organization profit.

\section{REFERENCES}

1. Malaysian Automotive Association. (2018). Malaysia Automotive Industry conference. Automotive industry.

2. Yusuf, A. (2017, July). Malaysia Automotive . Retrieved from trading economics:https://tradingeconomics.com/malaysia/car-registrations

3. Wad, P., \& Govindaraju, V. C. (2011). Automotive industry in Malaysia: an assessment of its development. International Journal of Automotive Technology and Management, 11(2), 152-171.

4. Natsuda, K., Segawa, N., John and Thoburn. (2012). Globalisation and the Malaysian Automotive Industry: Industrial Nationalism, Liberalisation, and the Role of Japan.

5. Talib, M.A., Munisamy, S. and Ahmed, S. (2012). Automotive Parts Manufacturing Industry: Unraveling The Efficacious Quality Framework. Interdisciplinary Journal of Contemporary Research in Business, 4(3), pp.217-26.

6. Department of Statistics Malaysia. (2015). Monthly Manufacturing Statistics Malaysia February 2015.

7. Gallup Incorporated. (2013). State of The Global Workplace: Employee Engagement Insight for Business Leaders Worldwide. Washington.

8. Akhtar, R. (2016). Climate Change and Human Health Scenario in South and Southeast Asia. Climate Change and Human Health Scenario in South and Southeast Asia.

9. Hibadullah, S.N., Fuzi, N.M., Desa, A.F.N.C. and Zamri, F.I.M. (2013). Lean Manufacturing Practices and Environmental Performance in

Malaysian Automotive Industr. Asian Journal of Finance \& Accounting , 5(1), pp.462-71.

10. Tan, J. (2017, November). Malaysia's vehicle. Retrieved from Motor Trader:http://www.motortrader.com.my/news/malaysia-s-vehicle-popul ation/

11. Kazimoto, P. (2016, March 25). Employee Engagement and Organizational Performance of Retails Enterprises. Employee Engagement and Organizational Performance of Retails Enterprises.

12. Calabrese, G. G. (2014). Automotive Technology and Management Automotive Technology and Management.

13. Rashid, N. (2018). Business Model for Sustainable Development: An Insight from Malaysian Automotive Industry. Business Model for Sustainable Development: An Insight from Malaysian Automotive Industry.

14. Shami, S. (2018). Sustainable Development. Malaysian Automotive Industry.

15. Malaysian-German Chamber of Commerce and Industry. (2012). Market Watch 2012: The Malaysian Automotive and Supplier Industry. Kuala Lumpur.

16. Wad, P. (2016). Automotive Industry in Malaysia: An Assessment of Its Development. Automotive Industry in Malaysia: An Assessment of Its Development.

17. Tan, P. (2018, January 18). Malaysian automotive industry outlook for 2018 - growth expected on all fronts, EEVs to climb to 60\%. Retrieved from Paultan.org https://paultan.org/2018/01/18/malaysian-automotive-industry-outlook -for-2018-growth-expected-on-all-fronts-eevs-to-climb-to-60/

18. Albrecht, S.L. (2010). Handbook of Employee Engagement: Perspectives, Issues, Research and Practice. Gloucestershire: Edward Elgar Publishing Ltd.

19. Kahn, W.A. (1990). Pschological Conditions of Personal Engagement and Disengagement At Work. Academy of Management Journal, 33(4), pp.692-724.

20. Rich, B.L., Lepine, J.A. and Crawford, E.R. (2010). Job Engagement: Antecedents and Effects on Job Performance. Academy of Management Journal, 53(3), pp.617-35.

21. Barrick, M. R., Thurgood, G. R., Smith, T. A., \& Courtright, S. H. (2015). Collective organizational engagement: Linking motivational antecedents, strategic implementation, and firm performance. Academy of Management journal, 58(1), 111-135.

22. Ravikumar, T. (2013). A Study on Impact of Team Work, Work Culture, Leadership and Compesation on Engagement Level of Employees In MSMES In India. International Journal of Advanced Research in Management and Social Sciences, 2(8), pp.175-85.

23. Tritch, T. (2003). Engagement Drives Results At New Century. Gallup Management Journal, p.4.

24. Medlin, B. and Green, K.W.J. (2014). Impact of Management Basics on Employee Engagement. Academy of Strategic Management Journal, 13(2), p.21.

25. Fachrunnisa, O., Adhiatma, A. and Mutamimah. (2014). The Role of Work Place Spirituality and Employee Engagement To Enhance Job Satisfaction and Performance. International Journal of Organization Innovation, 7(1), pp.15-35.

26. Saks, A.M. (2006). Antecedents and Consequences of Employee Engagement. Journal of Managerial Psychology, 21(7), pp.600 - 619.

27. Gonzalez-Roma, V., Schaufeli, W.B., Bakker, A.B. and Lloret, S. (2006). Burnout and Work Engagement: Independent Factos or Opposite Poles? Journal of Vocational Behavior, 68, pp.165-75.

28. Bettelley, C. (2015). What is employee engagement? Employee Benefits, p.1.

29. Fox, A. (2010). Raising Engagement. [Online] Available at: http://www.shrm.org/publications/hrmagazine/editorialcontent/2010/0 510/pages/0510fox.aspx [Accessed 10 March 2015].

30. Karanges, E.M., Beatson, A., Johnston, K. and Lings, I. (2014) Optimizing Employee Engagement with Internal Communication: A Social Exchange Perspective. Journal of Business Market Management, 7(2), pp.329-53

31. Jena, L. K. (2017). Research and recommendations for employee engagement: revisiting the employee-organization linkage. Research and recommendations for employee engagement: revisiting the employee-organization linkage.

32. Choo, L.S., Mat, N. and Al-Omari, M. (2013). Organizational Practices and Employee Engagement: A Case of Malaysia Electronics Manufacturing Firms. Business Strategy Series, 14(1), pp.3-10. 
33. Irshad, M. (2011). Factors Affecting Employee Retention: Evidence From Literature Review. Abasyn Journal of Social Sciences, 4(1), p.84.

34. Gohari, P., Ahmadloo, A., Boroujeni, M.B. and Hosseinipour, S.J. (2013). The Relationship between Rewards and Employee. Interdisciplinary Journal of Contemporary Research in Business, 5(3), pp.543-70

35. Ram, D.P. and Prabhakar, D.G.V. (2011). The Role of Employee Engagement in Work-related outcomes. Interdisciplinary Journal of Research in Business, 1(3), pp.47-61.

36. Anita, J. (2014). Determinants of Employee Engagement and Their Impact on Employee Performance. International Journal of Productivity and Performance Management, 63(3), pp.308-23.

37. Erturk, A. (2014). Influences of HR Practices, Social Exchange, and Trust on Turnover Intentions of Public IT Professionals. Public Personnel Management, 43(1), pp.140-75.

38. Permana, I., Tjakraatmadja, J.H., Larso, D. and Wicaksono, A. (2015). Exploring Potential Drivers of Employee Engagement, Enablement, and Empowerment: A Quest Toward Developing a Framework for Building Sustainable Employee Excellence for Manufacturing Environment in Indonesia. Mediterranean Journal of Social Sciences, 6(2), pp.577-87.

39. Saif, D.N.I. and Saleh, D.A.S. (2013). Psychological Empowerment and Job Satisfaction in Jordanian Hospitals. International Journal of Humanities and Social Science, 3(16), pp.250-57.

40. Ugwu, F.O., Onyishi, I.E. and Rodriguez-Sanchez, A.M. (2014). Linking Organizational Trust with Employee Engagement: The Role of Psychological Empowerment. Personnel Review, 43(3), pp.377-400.

41. Martocchio, J.J. (2006). Strategic Compensation: A Human Resource Management Approach. 4th ed. New Jersey: Pearson Education, Inc.

42. Ivancevish, J.M. (2007). Human Resource Management. 10th ed. New York: McGraw-Hill Irwin.

43. Hairudinor. (2014). The Effect of Compensation on the Psychological Well-Being,Work Engagement and Individual Performance (Case Study on The Nurses Of Private Hospitals In South Borneo, Indonesia). International Journal of Business and Management Invention, 3(7), pp.49-53.

44. Harunavamwe, M. and Kanengoni, H. (2013). The Impact of Monetary and Non-Monetary Rewards on Motivation Among Lower Level Employees in Selected Retail Shops. African Journal of Business Management, 7(38), pp.3929-35.

45. Moriarty, J. (2014). Compensation Ethics and Organizational Commitment. Business Ethics Quarterly, 24(1), pp.31-53.

46. Rashid, D.A.M. (2011). Career Development Interventions in Technical and Vocational Schools in Malaysia. The Journal of Human Resource and Adult Learning, 7(2), pp.23-33.

47. Patrick, D.H.A. and Kumar, A. (2011). Career Management, Employee Development and Performance in Indian Information Technology Organizations. Business Management Dynamics, 1(5), pp.24-31

48. Tulasi Das, D.V. and Vijayalakshmi, C. (2012). Employee Engagement Strategies For Enhancing Employee Competitiveness To Organizational Success. Indian Journal of Applied Research, 1(12), pp.137-40

49. Emery, C. R., \& Barker, K. J. (2007). The effect of transactional and transformational leadership styles on the organizational commitment and job satisfaction of customer contact personnel. Journal of organizational culture, communications and conflict, 11(1), 77.

50. Marquard, M. J. (2010). Leadership behavior impact on employee engagement. Pepperdine University.

51. Lee Whittington, J., \& Galpin, T. J. (2010). The engagement factor: Building a high-commitment organization in a low-commitment world. Journal of Business Strategy, 31(5), 14-24.

52. Swinton-Douglas, V. (2010). An exploratory study of employee engagement in the workplace: The employee perspective (Doctoral dissertation, Doctoral dissertation). Available from ProQuest Dissertations \& Theses Global.(UMI No. 3421055)).

53. Xu, J., \& Cooper Thomas, H. (2011). How can leaders achieve high employee engagement?. Leadership \& Organization Development Journal, 32(4), 399-416.

54. Arachchillage, G. (2017, August). Factors Affecting Employee Retention . Factors Affecting Employee Retention

55. Browell, S. (2003). Staff retention in a week. Great Britain: Hodder \& Stoughton.

56. Bidisha, L.D and Mukulesh, B. (2013), Employee Retention: A Review of Literature, Journal of Business and Management, 14 (2), 8-16.

57. Sahoo, S. R. (2017, May 11). Management of Stress at Workplace. Management of Stress at Workplace.

58. Panigrahi, A. (2017, February). Managing Stress at Workplace. Managing Stress at Workplace.

59. Gharib, M. (2016, May). The impact of job stress on job performance: A case study on academic staff at dhofar university. The impact of job stress on job performance: A case study on academic staff at dhofar university.

60. Wang. Y., Zheng, L., Hu, T., and Zheng, Q. (2014). Stress, burnout and job satisfaction: Case of Police Force in China. Public Personnel Management, Vol 43(3), 325-339.

61. Rothmann, S. (2014). Flourishing in work and careers. In M. Coetzee (Ed.), Psycho-social career meta-capacities: Dynamics of contemporary career development (pp. 203-220). Dordrecht, The Netherlands: Springer.

62. Bennett, H., \& Durkin, M. (2000). The effects of organisational change on employee psychological attachment: An exploratory study. Journal of Managerial Psychology, 15, 126-146.

63. Vakola, M., \& Nikolaou, I. (2005). Attitudes towards organizational change: What is the role of employees' stress and commitment. Employee Relations, 27, 160-174.

64. Paille.P (2011). Perceived stressful work, citizenship behavior and intention to leave the organization in a high turnover environment: Examining the mediating role of job satisfaction. Journal of Management Research, Vol 3(1).

65. Daniel, M., Alejandro, O.R. and Gabriela, G. (2014), Role Stress and Work Engagement as Antecedents of Job Satisfaction: Results From Portugal, Europe's Journal of Psychology, 2014, Vol. 10(2), 291-300.

66. Schaufeli, W.B. and Bakker, A.B. (2004) 'Job demands, job resources, and their relationship with burnout and engagement: a multi-sample study', Journal of Organisational Behaviour, Vol 25, 293-315.

67. Kuusio, H., Heponiemi, T., Vanska, J., Aalto, A.M., Ruskoaho, J., Elovainio, M. (2013), Psychosocial stress factors and intention to leave job: differences between foreign-born and Finnish-born general practitioners, Scandinavian Journal of Public Health, 2013; 41 $405-411$.

68. Jalagat, R. (2017, January). Determinants of Job Stress and Its Relationship on Employee Job Performance. Determinants of Job Stress and Its Relationship on Employee Job Performance.

69. Burman, R. (2017, June). A Systematic Literature Review of Work Stress. A Systematic Literature Review of Work Stress.

70. Davis, T.L. (2013), A Qualitative Study of the Effects of Employee Retention on the Organization, Insights to a Changing World Journal; 2013, Vol. 2013 Issue 2, p25

71. Simpson, M.R. (2009). Predictors of work engagement among medical surgical registered nurses. Western Journal Nursing Research, 31, 44-65.

72. Karlowicz, K.A., \& Ternus, M.P. (2007). Issues influencing psychiatric nurse retention during the first year of employment: a case analysis. Journal of Nursing Management, 17, 49-58.

73. Moncarz, E., Zhao, J. and Kay, C. (2009). An Exploratory Study of US Lodging Properties' Organizational Practices on Employee Turnover and Retention. International Journal of Contemporary Hospitality, 21(4), pp.437-58.

74. Bhatnagar, J. (2013). Talent management strategy of employee engagement in Indian ITES employees: key to retention. Talent management strategy of employee engagement in Indian ITES employees: key to retention.

75. Imam, A., \& Shafique, M. (2014). Impact of employee engagement in retaining employees through mediating effect of job satisfaction and organizational commitment and moderating effect of job stress: A Corporate banking sector study of Pakistan. Journal of Applied Environmental and Biological Sciences, 4(12), 1-15

76. Ministry of International Trade and Industry, 2018.Retrieved from https://www.miti.gov.my/index.php/pages/view/805?mid=67

77. Hair, Joseph F., et al. "Multivariate Data Analysis.(5. Bask1)." (1998).

78. Nunnally, J. (1978). Psychometric theory. New York: McGraw-Hill

79. Hair, J. F. Jr., Black, W. C., Babin, B. J., Anderson R. E., \& Tatham, R. L. (2006). Multivariate Data Analysis (6th ed.), Upper Saddle River, NJ Prentice Education, Inc.

80. Ndungu, D. N. (2017). The Effects of Rewards and Recognition on Employee Performance in Public Educational Institutions: A Case of Kenyatta University, Kenya. Global Journal of Management And Business Research.

81. Rana, S. (2019). Managing Organizations Through Employee Engagement: An Indian Perspective. In Management Techniques for Employee Engagement in Contemporary Organizations (pp. 256-267). IGI Global. 


\section{AUTHOR'S PROFILE}

Vimala Kadiresan HELP University, Selangor,Malaysia, The area of research includes, Management. Human Resource Management, Training and Development.

Wong Sook Khuan, KDU University College, Malaysia

Thangaraja Arumugam, Vellore Institute of Technology, Chennai, Tamilnadu, India.

Farrell Rasu, National Institute of Public Administration (INTAN), Bukit Kiara, Kuala Lumpur, Malaysia

Anastashia Shawna Theseira Segi University, Kota Damansara , Selangor, Malaysia 